\title{
Protection of p53 wild type cells from taxol by nutlin-3 in the combined lung cancer treatment
}

\author{
Sergey V Tokalov*, Nasreddin D Abolmaali
}

\begin{abstract}
Background: Mutations within the tumor suppressor TP53 gene are one of the most common genetic alterations present at high frequency in human tumors and have been shown to be associated with resistance to radiochemotherapy. The lack of the wild type TP53 gene in cancer cells could be exploited for therapeutic advantage using a sequence of two antagonistic drugs. The aim of this study was to selectively kill p53 deficient cells (FaDu and H1299) by taxol and to protect p53 wild type cells (A549) by the prior administration of nutlin-3 in comparison to certain known anticancer drugs (5-fluorouracil, camptothecin, roscovitine).
\end{abstract}

Methods: Cytotoxic and cytostatic properties of 5-fluorouracil, camptothecin, roscovitine and nutlin-3 administrating alone or in combination with taxol were investigated in vitro by flow cytometry.

Results: It was found that nutlin-3 induced growth arrest and protected A549 cells from taxol. FaDu and H1299 cells responded to the same treatments with mitotic arrest and massive apoptosis. Other compounds (5-fluorouracil, camptothecin and roscovitine) revealed weaker selectivity and elevated toxicity in comparison to nutlin-3.

Conclusions: We propose a therapeutic strategy protecting normal cells from taxol while increasing apoptosis selectively in p53-deficient cells using nutlin-3.

\section{Background}

Cancer is a complex family of diseases, characterized by the deregulation of normal control pathways for cellular growth. Lung cancer (LC) is the leading cause of death among human malignancies and is among the most threatening of them due to its disappointing response to therapy [1]. Development of LC, which can be separated roughly into small cell lung cancer (SCLC) or non-small cell lung cancer (NSCLC), involves multiple genetic abnormalities. One of the most common changes on this way is mutation in the tumor suppressor TP53 gene with a mutations frequency of $50 \%$ and $70 \%$ in NSCLC and SCLC, respectively [2-4]. Such genetic abnormality is shown to be associated with a poorer survival prognosis and increased cellular resistance to therapy [5-7]. Thus, there is an urgent need for development of targetdriven novel class of anti-cancer drug against this deadly disease.

\footnotetext{
* Correspondence: Sergey.Tokalov@oncoray.de
OncoRay - Center for Radiation Research in Oncology, Medical Faculty Carl

* Correspondence: Sergey.Tokalov@oncoray.de
OncoRay - Center for Radiation Research in Oncology, Medical Faculty Carl Gustav Carus, Dresden University of Technology, Fetscherstraße 74/P.O. Box 86, 01307 Dresden, Germany
}

(c) 2010 Tokalov and Abolmaali; licensee BioMed Central Ltd. This is an Open Access article distributed under the terms of the Creative Commons Attribution License (http://creativecommons.org/licenses/by/2.0), which permits unrestricted use, distribution, and reproduction in any medium, provided the original work is properly cited. gets is mainly based on the identification of genes involved in pathways selectively exploited in cancer cells $[8,9]$. For example, the lack of wt p53 (the product of TP53 gene) in cancer cells can be utilized for therapeutic advantage by selective killing of p53 deficient ( $553^{-/-}$) cancer cells and by protecting p53 wild type cells $\left(\mathrm{p} 53^{\mathrm{wt}}\right)$ at normal proliferation rates using antagonistic drugs $[10,11]$. It was demonstrated that certain anticancer drugs could selectively arrest $\mathrm{p} 53^{\mathrm{wt}}$ cells in $\mathrm{G}_{1}$ or $\mathrm{G}_{2}$ phases of the cell cycle by activation of the p53 pathway and thereby protects them from antimitotic agent. E.g. taxol, which simultaneously kills and/or blocks $\mathrm{p} 53^{-1-}$ cancer cells during mitosis [12,13].

However, genotoxic drugs can trigger multiple molecular events including activation of p53-independent checkpoints and thus may partially protect the cancer cells during chemotherapy [3]. This can be avoided by using agents targeted specifically at the p53 pathway. In proliferating cells that are not subjected to stress, p53 level is tightly controlled by its negative regulator MDM2, which binds p53 and modulates its 
transcriptional activity and stability [3,14-16]. MDM2 is an E3 ubiquitin ligase that binds the tumor suppressor and facilitates its ubiquitin-dependent degradation [17]. The MDM2 binding domain overlaps with the transcriptional activation domain of p53, and therefore MDM2 binding also inhibits the transcriptional activity of p53, thus effectively impairing its function [18]. Disruption of the p53-MDM2 interaction, therefore, provides an attractive strategy for activating p53. It was shown that nutlin-3 could selectively disrupt the interaction between p53 and MDM2 [19] inducing cell cycle arrest in normal murine and human cells $[3,14-16,20]$ cells without initiation of apoptosis. This presents unique opportunities for p53-dependent modulation of the cell cycle of the proliferating $\mathrm{p} 53^{\mathrm{wt}}$ cells of the intact surrounding tissues to protect them from the taxol during chemotherapy of $\mathrm{p} 53^{-/-}$tumors [21].

In this context, the goal of our work was to evaluate the effectiveness of the MDM2 antagonist nutlin-3 in comparison to certain anticancer drugs (5-fluorouracil, camptothecin, roscovitine) with known cytostatic effects to protect proliferating $\mathrm{p} 53^{\mathrm{wt}}$ cells from taxol in the combined cell cycle associated therapy leading to selective killing of $\mathrm{p} 53^{-/-}$cells.

\section{Methods}

\section{Cell culture}

Established human cell lines of different tumor entities, i.e. near triploid ( 3C) NSCLC cell line A549 presenting wild type TP53 gene, near hexaploid ( 6C) NSCLC cell line H1299 with TP53-null gene and near triploid ( 3C) pharyngeal squamous-cell carcinoma (PSCC) cell line FaDu presenting mutated TP53 gene from DSMZ (Germany) were used in this study. Cells were cultured in Dulbecco Modified Eagle Medium routinely supplementing with $10 \%$ heat-inactivated fetal calf serum (Gibco, France) and incubated at $37^{\circ} \mathrm{C}$ in humidified $5 \%$ $\mathrm{CO}_{2}$ atmosphere with media replacement every 2 days. When the cell cultures reached $90 \%$ confluence they were harvested using $0.25 \%$ trypsin and $1 \mathrm{mM}$ EDTA solution (Sigma, Germany) and reseeded in new flasks at a density of 10-15 $\times 10^{3}$ cells $/ \mathrm{cm}^{2}$. Cell counts in the samples were determined with a coulter counter (CASY, Model TTC, Schärfe System, Germany).

\section{Flow cytometry}

To have a possibility for comparison of our results with previousfindings [3,12,14-16,19,20,22-28] and taking into account that in solid tumor-derived cell lines p53-dependent apoptosis is usually delayed for $24 \mathrm{~h}$ [19] the cells were placed in culture medium $\left(2 \times 10^{5}\right.$ cells $\left./ \mathrm{mL}\right) 1$ day before exposure to 5 -fluorouracil $(1,3,10$ and $30 \mu \mathrm{M})$, camptothecin (10, 30, 100 and $300 \mathrm{nM})$, nutlin-3 (1, 3, 10 and $30 \mu \mathrm{M})$, roscovitine $(1,3,10$ and $30 \mu \mathrm{M})$ and taxol
$(1,3,10,30$ and $100 \mathrm{nM})$. All compounds were pursued from Sigma (Germany). To test an advantage of the nutlin-3 in the selective protect p53 ${ }^{\mathrm{wt}}$ A549 cells from taxol, all cell cultures according to [3,29] were incubated for a 24 hours period in parallel with 5-fluorouracil $(3 \mu \mathrm{M})$, camptothecin $(10 \mathrm{nM})$, roscovitine $(10 \mu \mathrm{M})$ and nutlin-3 $(3 \mu \mathrm{M})$ respectively. Then, taxol $(10 \mathrm{nM})$ was added and cell cultures were incubated for another 24 hours period. Because the stock solutions $(\times 1000)$ of the test compounds were prepared in dimethylsulfoxid (DMSO, Sigma, Germany), all cultures including the control samples were made $0.1 \%$ in DMSO. After 24 hours of appropriate treatment cells were removed from the culture and prepared for analysis by flow cytometry as previously described [30]. Cells were briefly washed with phosphate-buffered saline (PBS) and centrifuged at $100 \mathrm{~g}$ for $10 \mathrm{~min}$. The cell pellet was re-suspended in $100 \mu \mathrm{l}$ of PBS, fixed in $70 \%$ ( $\mathrm{vol} / \mathrm{vol}$ ) ethanol by adding $1 \mathrm{ml}$ of cold $\left(-20^{\circ} \mathrm{C}\right)$ ethanol and stored overnight at $-20^{\circ} \mathrm{C}$. The cells were spun down again and the pellet was suspended in $1.5 \mathrm{ml}$ of PBS at room temperature. After centrifugation the cell pellet was suspended in $1 \mathrm{ml}$ DNA staining solution containing $50 \mu \mathrm{g}$ PI and $0.2 \mathrm{mg}$ RNase (both Sigma, Germany) and incubated for at least $45 \mathrm{~min}$ at room temperature in the dark. About $2 \times 10^{5}$ cells per sample were analyzed by flow cytometry (CyFlow, Partec, Germany). The excitation wavelength was $488 \mathrm{~nm}$, and red fluorescence ( $>590 \mathrm{~nm}$ for PI) was recorded. In addition, the parameters for forward scatter (FSC) and side scatter (SSC) were determined. For each variable (exposure condition, culture period etc.) a minimum of 6 samples were quantified. The flow cytometer was calibrated with $2.5 \mu \mathrm{m}$ polyfluorescent beads (AlignFlow, Molecular Probes, Eugene, OR) before each series of measurements.

The fractions of apoptotic cells with sub- $G_{1}$ DNA content as well as the fractions of cells in $G_{0+1}, S$ and $\mathrm{G}_{2}+\mathrm{M}$ phases of the cell cycle were quantified according to the level of measured fluorescence, FSC and SSC using a CyFlow software (Partec, Germany).

\section{Statistics}

The experimental results are expressed as the mean \pm standard deviation (mean \pm s.d.) of 6 independent experiments. Analysis of variance (ANOVA) was performed.

\section{Results}

In vitro cultures of exponentially growing A549, H1299 and $\mathrm{FaDu}$ intact cell cultures had different cell cycle distributions with $62 \pm 1 \%, 46 \pm 1 \%$ and $59 \pm 1 \%$ in $\mathrm{G}_{0+1}$, $26 \pm 1 \%, 36 \pm 1 \%$ and $26 \pm 1 \%$ in $\mathrm{S}$ and $12 \pm 1 \%, 18 \pm$ $1 \%$ and $15 \pm 1 \%$ in $G_{2}+M$ phases respectively. In the first part of investigation all cell cultures were incubated for a 24 hours period in parallel with dissimilar 
concentrations of 5-fluorouracil, camptothecin, nutlin-3, roscovitine and taxol with respect to the toxicity and cell cycle effects of test compounds.

No perturbations of the cell cycle were registered in the control cell cultures. With increasing concentrations of the tested compounds the cell cycle progression was affected in varying degrees (Table 1).

5 -fluorouracil provoked a dose dependent delay in $\mathrm{S}$ phase $(3-30 \mu \mathrm{M}, \mathrm{p}<0.05)$ in all three cell lines independent of their p53 status. It was accompanied by decreasing percentage of $\mathrm{G}_{0+1}$ cells in A549 $(10-30 \mu \mathrm{M}$, $\mathrm{p}<0.05), \mathrm{FaDu}(10 \mu \mathrm{M}, \mathrm{p}<0.05)$ and $\mathrm{H} 1299(3-30 \mu \mathrm{M}$, $\mathrm{p}<0.05)$.

Camptothecin was the most toxic of the test compounds used showing a dose dependent increase of apoptotic cell proportion $(\mathrm{p}<0.05)$, causing cell cycle arrest at $S$ phase $(p<0.05)$ and reduction of $G_{0}+1$ cells proportion $(\mathrm{p}<0.05)$ at concentrations of $30-300 \mathrm{nM}$ in all three cell lines independent of their p53 status.

Nutlin-3 at concentrations of 3-30 M caused reduction of $S$ cells proportion $(\mathrm{p}<0.05)$ with increase of percentage in $G_{0+1}(p<0.05)$ and $G_{2}+M$ phases $(p<$ $0.05)$ in $\mathrm{p} 53^{\mathrm{wt}} \mathrm{A} 549$ cells. No remarkable changes in the cell cycle distribution were registered in $\mathrm{p} 53^{-1-} \mathrm{FaDu}$ and H1299 cells. These observations were accompanied by an increasing proportion of apoptotic cells $(30 \mu \mathrm{M}$, $\mathrm{p}<0.05)$ in all cell lines used.

Roscovitine caused increase of A549 (3-30 $\mu \mathrm{M}, \mathrm{p}<$ 0.05), $\mathrm{FaDu}(3-30 \mu \mathrm{M}, \mathrm{p}<0.05)$ and $\mathrm{H} 1299(10-30 \mu \mathrm{M}$, $\mathrm{p}<0.05)$ cells proportion at $\mathrm{G}_{2}+\mathrm{M}$ phase. Decreases of $\mathrm{G}_{0}+1$ cells percentage were registered in A549 $(30 \mu \mathrm{M}, \mathrm{p}<0.05), \mathrm{FaDu}(10-30 \mu \mathrm{M}, \mathrm{p}<0.05)$ and

Table 1 Effects of test substances on proliferation of certain cancer cells.

\begin{tabular}{|c|c|c|c|c|c|c|c|c|c|c|c|c|}
\hline \multicolumn{13}{|c|}{ The distribution of cells in different cell cycle phases $(\%)^{1}$} \\
\hline & \multicolumn{4}{|c|}{ A549 } & \multicolumn{4}{|c|}{ FaDu } & \multicolumn{4}{|c|}{ H1299 } \\
\hline & $<2 \mathrm{C}^{2}$ & $\mathrm{G}_{0+1}$ & $\mathbf{S}$ & $\mathrm{G}_{2}+\mathrm{M}$ & $<2 C$ & $\mathrm{G}_{0+1}$ & S & $\mathrm{G}_{2}+\mathrm{M}$ & $<2 C$ & $\mathrm{G}_{0+1}$ & S & $\mathrm{G}_{2}+\mathrm{M}$ \\
\hline \multicolumn{13}{|c|}{ 5-fluorouracil ( $\mu \mathrm{M})$} \\
\hline 1 & $2 \pm 1$ & $62 \pm 2$ & $27 \pm 1$ & $11 \pm 1$ & $2 \pm 1$ & $51 \pm 3$ & $31 \pm 2$ & $16 \pm 1$ & $2 \pm 1$ & $56 \pm 2$ & $31 \pm 2$ & $15 \pm 1$ \\
\hline 3 & $2 \pm 1$ & $57 \pm 2$ & $33 \pm 1$ & $10 \pm 1$ & $2 \pm 1$ & $55 \pm 3$ & $26 \pm 2$ & $19 \pm 1$ & $2 \pm 1$ & $52 \pm 2$ & $34 \pm 2$ & $14 \pm 1$ \\
\hline 10 & $2 \pm 1$ & $31 \pm 2$ & $61 \pm 2$ & $8 \pm 2$ & $2 \pm 1$ & $28 \pm 1$ & $52 \pm 1$ & $20 \pm 1$ & $2 \pm 1$ & $52 \pm 2$ & $32 \pm 2$ & $16 \pm 2$ \\
\hline 30 & $3 \pm 1$ & $46 \pm 2$ & $47 \pm 2$ & $7 \pm 2$ & $3 \pm 1$ & $48 \pm 2$ & $44 \pm 1$ & $18 \pm 1$ & $5 \pm 1$ & $50 \pm 2$ & $33 \pm 2$ & $17 \pm 2$ \\
\hline \multicolumn{13}{|c|}{ Camptothecin (nM) } \\
\hline 10 & $2 \pm 1$ & $42 \pm 4$ & $24 \pm 2$ & $28 \pm 3$ & $6 \pm 2$ & $18 \pm 1$ & $24 \pm 2$ & $58 \pm 3$ & $2 \pm 1$ & $17 \pm 4$ & $40 \pm 9$ & $43 \pm 9$ \\
\hline 30 & $8 \pm 2$ & $16 \pm 2$ & $68 \pm 4$ & $16 \pm 4$ & $10 \pm 3$ & $6 \pm 1$ & $77 \pm 3$ & $17 \pm 3$ & $12 \pm 2$ & $11 \pm 3$ & $69 \pm 3$ & $19 \pm 2$ \\
\hline 100 & $32 \pm 4$ & $14 \pm 2$ & $69 \pm 4$ & $17 \pm 2$ & $17 \pm 2$ & $21 \pm 3$ & $68 \pm 4$ & $11 \pm 1$ & $17 \pm 3$ & $22 \pm 1$ & $56 \pm 4$ & $22 \pm 3$ \\
\hline 300 & $45 \pm 6$ & $45 \pm 4$ & $45 \pm 4$ & $10 \pm 2$ & $15 \pm 3$ & $40 \pm 3$ & $50 \pm 3$ & $10 \pm 2$ & $15 \pm 2$ & $35 \pm 3$ & $40 \pm 4$ & $25 \pm 2$ \\
\hline \multicolumn{13}{|c|}{ Nutlin-3 ( $\mu \mathrm{M})$} \\
\hline 1 & $2 \pm 1$ & $61 \pm 2$ & $28 \pm 2$ & $11 \pm 1$ & $2 \pm 1$ & $40 \pm 4$ & $38 \pm 3$ & $22 \pm 3$ & $2 \pm 2$ & $57 \pm 1$ & $29 \pm 2$ & $14 \pm 1$ \\
\hline 3 & $2 \pm 1$ & $71 \pm 2$ & $13 \pm 1$ & $16 \pm 1$ & $2 \pm 1$ & $44 \pm 2$ & $34 \pm 2$ & $22 \pm 2$ & $2 \pm 1$ & $57 \pm 3$ & $25 \pm 2$ & $18 \pm 2$ \\
\hline 10 & $2 \pm 1$ & $69 \pm 1$ & $7 \pm 3$ & $24 \pm 3$ & $4 \pm 1$ & $45 \pm 3$ & $34 \pm 2$ & $21 \pm 2$ & $4 \pm 1$ & $54 \pm 4$ & $27 \pm 4$ & $19 \pm 2$ \\
\hline 30 & $5 \pm 1$ & $68 \pm 2$ & $6 \pm 1$ & $26 \pm 2$ & $8 \pm 1$ & $48 \pm 3$ & $32 \pm 2$ & $20 \pm 2$ & $7 \pm 1$ & $63 \pm 2$ & $19 \pm 2$ & $18 \pm 1$ \\
\hline \multicolumn{13}{|c|}{ Roscovitine $(\mu \mathrm{M})$} \\
\hline 1 & $2 \pm 1$ & $60 \pm 2$ & $24 \pm 2$ & $16 \pm 1$ & $2 \pm 1$ & $41 \pm 4$ & $39 \pm 4$ & $20 \pm 2$ & $2 \pm 1$ & $47 \pm 1$ & $36 \pm 3$ & $17 \pm 2$ \\
\hline 3 & $2 \pm 1$ & $59 \pm 4$ & $20 \pm 3$ & $21 \pm 1$ & $2 \pm 1$ & $43 \pm 1$ & $32 \pm 1$ & $25 \pm 1$ & $2 \pm 1$ & $52 \pm 1$ & $33 \pm 1$ & $15 \pm 2$ \\
\hline 10 & $5 \pm 1$ & $59 \pm 4$ & $20 \pm 3$ & $21 \pm 1$ & $4 \pm 1$ & $38 \pm 2$ & $27 \pm 2$ & $35 \pm 2$ & $4 \pm 2$ & $49 \pm 2$ & $29 \pm 1$ & $22 \pm 1$ \\
\hline 30 & $10 \pm 4$ & $51 \pm 5$ & $24 \pm 3$ & $24 \pm 3$ & $10 \pm 3$ & $34 \pm 3$ & $30 \pm 2$ & $36 \pm 2$ & $11 \pm 4$ & $43 \pm 3$ & $26 \pm 2$ & $31 \pm 3$ \\
\hline \multicolumn{13}{|c|}{ Taxol (nM) } \\
\hline 1 & $9 \pm 2$ & $60 \pm 4$ & $25 \pm 4$ & $15 \pm 2$ & $21 \pm 2$ & $39 \pm 3$ & $34 \pm 6$ & $27 \pm 4$ & $13 \pm 6$ & $48 \pm 6$ & $30 \pm 3$ & $22 \pm 5$ \\
\hline 3 & $36 \pm 5$ & $41 \pm 3$ & $32 \pm 5$ & $27 \pm 2$ & $30 \pm 5$ & $22 \pm 4$ & $35 \pm 5$ & $43 \pm 7$ & $35 \pm 6$ & $40 \pm 1$ & $40 \pm 1$ & $20 \pm 1$ \\
\hline 10 & $35 \pm 6$ & $22 \pm 4$ & $29 \pm 3$ & $51 \pm 6$ & $33 \pm 6$ & $12 \pm 2$ & $19 \pm 4$ & $69 \pm 4$ & $42 \pm 5$ & $34 \pm 4$ & $34 \pm 4$ & $32 \pm 7$ \\
\hline 30 & $16 \pm 4$ & $15 \pm 2$ & $17 \pm 3$ & $68 \pm 5$ & $16 \pm 3$ & $4 \pm 1$ & $11 \pm 2$ & $85 \pm 2$ & $44 \pm 4$ & $18 \pm 1$ & $36 \pm 4$ & $46 \pm 7$ \\
\hline 100 & \multicolumn{11}{|c|}{ Control } & $55 \pm 2$ \\
\hline-3 & $2 \pm 1$ & $62 \pm 1$ & $26 \pm 1$ & $12 \pm 1$ & $2 \pm 1$ & $46 \pm 2$ & $36 \pm 1$ & $18 \pm 1$ & $2 \pm 1$ & $59 \pm 2$ & $26 \pm 2$ & $15 \pm 1$ \\
\hline
\end{tabular}

The data show the effects of the test substances on the cell cycle of A549, FaDu and H1299 cells after exposure for 1 day (average \pm SD of 6 independent experiments). Significant differences $(p<0.05)$ to control cultures are indicated in bold print.

${ }^{1}$ The distribution of cells in different cell cycle phases was calculated from the population of cycling cells $\left(G_{0}+1+S+G_{2}+M=100 \%\right)$.

${ }^{2}$ The percentage of hypodiploid cells ( $<2 C$ DNA content) was calculated from the total number of cells.

${ }^{3}$ Since the test compounds were dissolved in a DMSO stock solution, control cells cultures were made in $14 \mathrm{mM}(0.1 \%)$ DMSO. 
H1299 (1-30 $\mu \mathrm{M}, \mathrm{p}<0.05)$ cells. These changes were accompanied by the increasing proportion of apoptotic cells $(30 \mu \mathrm{M}, \mathrm{p}<0.05)$ in all three cell lines.

Taxol caused dose dependent accumulation of cells arresting at the $G_{2}+M$ phase accompanied by the reduction of the proportion of the cells in $G_{0+1}$ and $S$ phases $(3-100 \mu \mathrm{M}, \mathrm{p}<0.05)$ independent of their p53 status. At lower concentrations $(1-30 \mathrm{nM}, \mathrm{p}<0.05)$, a large fraction of cells was released from the block in 24 hours and became apoptotic. At higher concentrations (30-100 $\mathrm{nM})$ the proportion of apoptotic cell was reduced due to elongation of $\mathrm{G}_{2}+\mathrm{M}$ block.

To test the ability of the analyzed compounds to selectively protect $\mathrm{p} 53^{\mathrm{wt}}$ A549 cells and to selectively kill p53 ${ }^{-/-} \mathrm{H} 1299$ and FaDu cells by taxol, all cell cultures were incubated for a 24 hours period in parallel with DMSO (0.1\%, control), 5-fluorouracil (3 $\mu \mathrm{M})$, camptothecin $(10 \mathrm{nM})$, roscovitine $(10 \mu \mathrm{M})$, nutlin-3 $(3 \mu \mathrm{M})$ and taxol (Tax, $10 \mathrm{nM})$ respectively (Figure 1). Then, taxol (10 nM) was added and cell cultures were incubated for another 24 hours period. It was found (Figure 2) that the administration of taxol alone increased the proportion of apoptotic cells in A549 (35 $\pm 6 \%, \mathrm{p}<0.001), \mathrm{FaDu}(33 \pm 4 \%, \mathrm{p}<0.001)$ and H1299 $(42 \pm 5 \%, p<0.001)$ cell lines. Pretreatment with nutlin3 protected p53 ${ }^{\mathrm{wt}}$ A549 cells (but not p $53^{-/-} \mathrm{FaDu}$ and H1299 cells) from taxol, dramatically reduced the proportion of apoptotic cells $(2 \pm 1 \%, \mathrm{p}<0.001 ; 29 \pm 2 \%$, p $<0.001 ; 52 \pm 4 \%, \mathrm{p}>0.05$, correspondently) and revealed the similar distribution through the cell cycle, as it was registered after the administration of nutlin-3 alone.

Pretreatment with roscovitine also protected some of A549. However, roscovitine increased proportion of apoptotic A549 cells as well as protected some of $\mathrm{p} 53^{-1-}$ FaDu cells due to a block in $G_{2}+M$ phase. As a result proportion of apoptotic A549, FaDu and H1299 cells reduced to $20 \pm 2 \%, \mathrm{p}<0.001 ; 21 \pm 2 \%, \mathrm{p}<0.001 ; 49 \pm$ $3 \%, \mathrm{p}>0.05$, correspondently. The other compounds analyzed (5-fluorouracil, camptothecin) revealed low selectivity and demonstrated high toxicity as well.

\section{Discussion}

Our findings in cell cycle specific interaction of anticancer drugs (5-fluorouracil, camptothecin, nutlin-3, roscovitine, taxol) generally validate previous reports in the literature. So, it is confirmed that treatment of cells with 5 -fluorouracil widely using in the treatment of a range of cancers leads to an accumulation of cells in S-phase and induces p53 apoptosis [22]. Naturally occurring cytotoxic alkaloid camptothecin reveals the highest toxicity from the test compounds due to the possibility irreversibly binding to the DNA-topoisomerase I complex independent of 53 status of cells [23]. Roscovitine inhibiting cyclin-dependent kinases via direct competition in the ATP-binding site [26] provokes $\mathrm{G}_{2}-\mathrm{M}$ arrest and at the highest using doses induces apoptosis in all of used cells. Following binding to B-tubulin microtubule-targeted agent taxol causes mitotic arrest and apoptosis in variety of cancer cells [27]. Such blocked cells could be

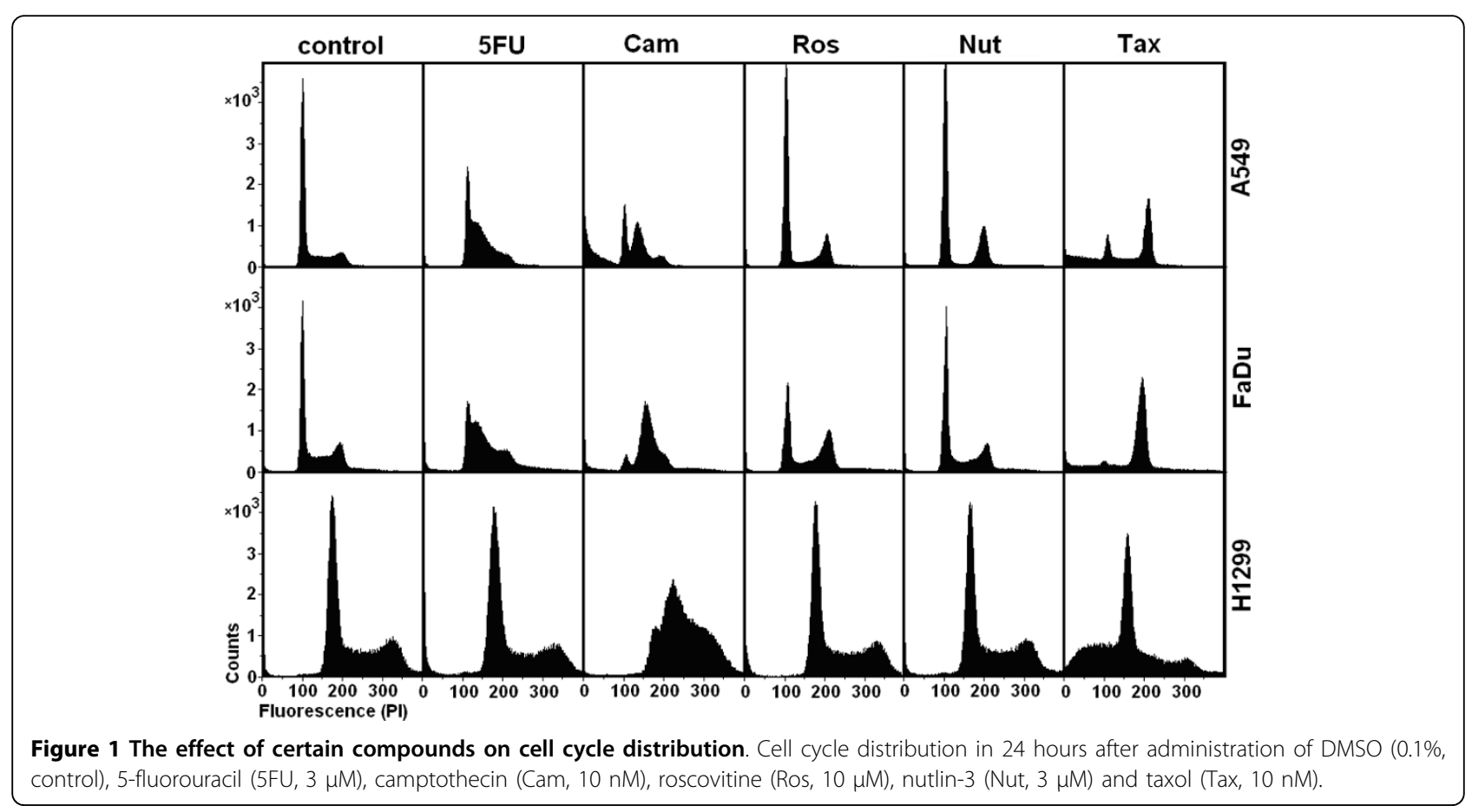




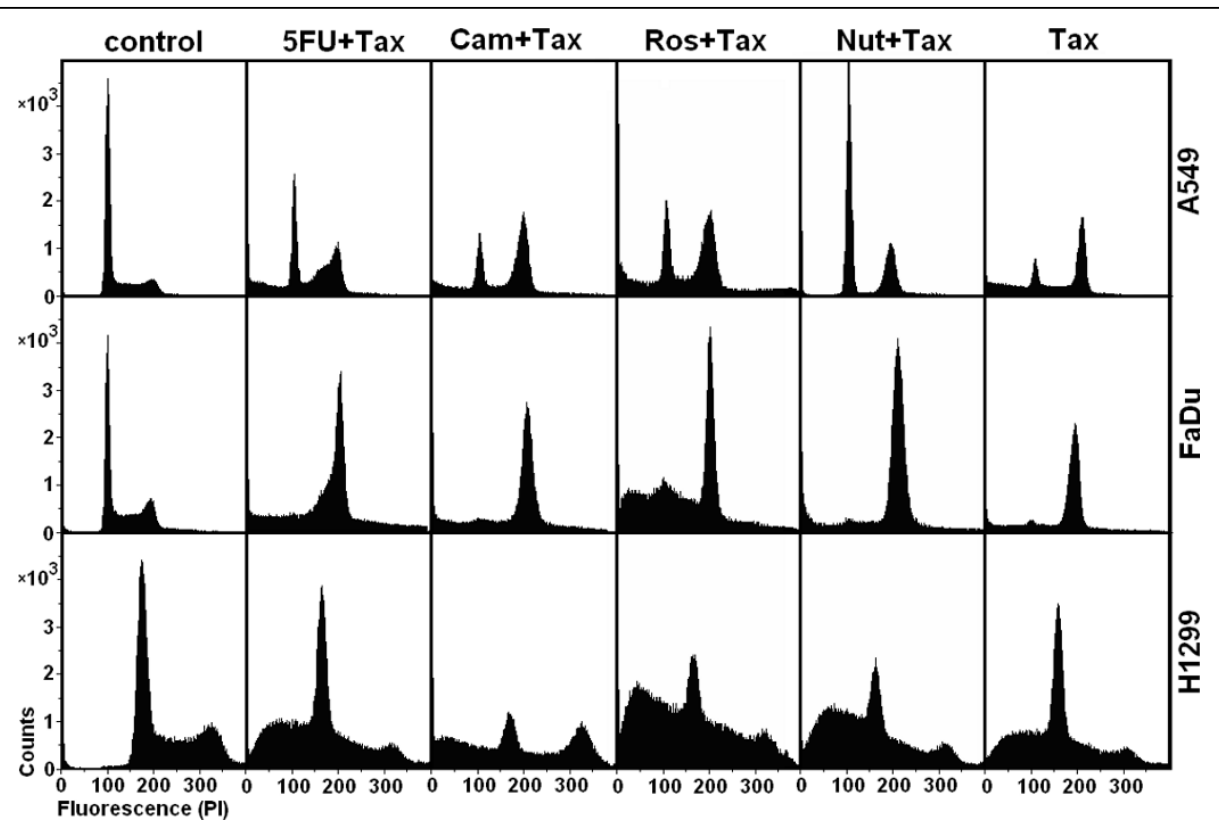

Figure 2 Cell cycle distribution in $\mathbf{2 4}$ hours after combined treatment. Cell cycle distribution in 24 hours after administration of DMSO $(0.1 \%$, Control), 5-fluorouracil (5FU, $3 \mu \mathrm{M})$, camptothecin (Cam, $10 \mathrm{nM})$, roscovitine (Ros, $10 \mu \mathrm{M})$, nutlin-3 (Nut, $3 \mu \mathrm{M})$, followed by administration of taxol (Tax, $10 \mathrm{nM}$ ) for another 24 hours.

arrested during next several days of culture. In contrast, at lower concentrations a large fraction of cells could release from the block in 24 hours and became apoptotic [28]. Our study in agreement with previous findings [31] showed that nutlin-3 in low concentrations (1-10 $\mu \mathrm{M})$ induced depletion of the $\mathrm{S}$-phase fraction, causing arrest at $G_{1} / S$ and/or $G_{2} / M$ phases in p53 ${ }^{\text {wt }}$ A549 cells without apparent apoptosis. Last may be explained by the known fact that the induction of apoptotic genes alone sometimes is not sufficient to provoke apoptosis, as the high levels of cell cycle inhibitor, such as p21 dominantly lead to the cell cycle arrest [24]. This was supported using MI-43 (another compound that disrupted Mdm2-p53 binding) which at low concentrations induced remarkable induction of p53 leading to $90 \%$ cells arrested of A549 cells at the $\mathrm{G}_{1}$ phase without apparent apoptosis, although Puma and Noxa were also induced. However, at higher drug concentration cells underwent apoptosis even with a moderate further increase of Puma and Noxa abbrgrp $>25]$.

Previous studies show that elevated concentrations of nutlin-3 induced p53- and p21-dependent cell cycle arrest and p53-dependent cell death in different $\mathrm{p} 53^{\mathrm{wt}}$ tumor cell lines including A549 [15,16,18,19,21,25, $27,29,31]$. The p53 activation by nutlin-3 has been shown to lead cell cycle arrests in normal human $[3,15]$ fibroblasts, endothelial [16] and epithelial [20] cells without initiation of apoptosis. Therefore, NSCLC cell line A549 seems to be more sensitive to the induction of apoptosis through the activation of p53 pathway and our results might be translated to the control cell lines mentioned above.

Taxol and other mitotic chemotherapeutics are frequently used together with genotoxic drugs activating the p53 pathway in wild-type p53 cells via genotoxic stress [10]. However, the usefulness of DNA damaging agent is limited by their ability to activate p53-independent checkpoint mechanism in cancer cells with mutant p53 [11]. The nutlin-3 works solely through stabilization and activation of p53 gene. Therefore, protection by nutlin-3 is strictly dependent on the p53 status of the cells [21]. Using MDM2 antagonist nutlin-3 as selective activator of p53 pathway, we have shown that induction of cell cycle arrest can protect p53 ${ }^{\mathrm{wt}}$ NSCLC (A549) cells from the cytotoxicity of taxol selectively killing of p5 $3^{-1-}$ PSCC cells (FaDu) and p53 $3^{-1-}$ NSCLC (H1299) cells. Our results confirmed previously reported synergistic interaction of the nutlin-3/taxol treatment of the $\mathrm{p} 53^{-/-}$cancer cells and protection of normal proliferating fibroblasts or $\mathrm{p} 53^{\mathrm{wt}}$ colon cancer cells [3].

Although the experiments described in this report use taxol as a mitotic inhibitor, nutlin-3 halted cell cycle progression at the $G_{1} / S$ and $G_{2} / M$ phases and can thus attenuate the activity of S-phase- and M-phase-specific drugs. For example, treatment of normal proliferating fibroblasts or keratinocytes with nutlin-3 protects these cells against gemcitabine and Ara-C killing proliferating p53-/- cancer cells in S-phase [29]. 
From other side, previous findings have suggested that nutlin-3 at higher concentrations might also offer a new therapeutic option to patients with tumors that express wild-type p53 either as single agent (Vassilev, 2005; Tovar et al., 2005) or as combination therapy (Kojima et al., 2005; Stuhmer et al., 2005). Nutlins have been shown to enter multiple types of cultured cells and inhibit the p53-MDM2 interaction in the cellular context with a high degree of specificity, resulting in the p53 stabilization, p21 induction, cell cycle arrest in G1 and G2 phases, apoptosis and growth inhibition of proliferating cancer cells [19]. It is interesting that treatment of nude mice with nutlin-3 has been shown might effectively inhibit the growth of tumor xenografts without revealing of overt toxicity, thus suggesting that normal tissues may have higher tolerance to p53 activation [21].

Our findings open possibility to establish a genetically determined strategy in the lung cancer treatment. Depending of genetic status of tumor nutlin-3 might be administrated as an agent for activation of the p53 pathway resulting in p53 stabilization, p21 induction, cell cycle arrest in $G_{1}$ and $G_{2}$ phases, apoptosis and growth inhibition of cancer cells or in combination with taxol as a compound protecting surrounding normal tissue. However, an inter-organ metabolism of nutlin-3 might be critical to its absorption, distribution and modification of the resulting therapeutic effects in vivo.

Therefore, additional in vivo experiments in which the therapeutic role of nutlin-3 is assessed on multiple normal tissues in human tumor xenografts with different p53 status may help to better understand the clinical potential of this approach.

\section{Conclusions}

The therapeutic strategy protecting normal cells from taxol, while selectively increasing apoptosis in p53-deficient cells is proposed. Nutlin-3 application opens possibility to establish a genetically determined strategy in the lung cancer treatment. However, metabolism of used compounds in different tissues should be taken into account for evaluation of therapeutic effects of this approach.

\section{Acknowledgements}

This research and the authors are supported by the Federal Ministry of Education and Research, Germany, BMBF Contract 03ZIK042.

\section{Authors' contributions}

SVT carried out the literature search, designed the study performed in vitro cell culture, cell treatment, flow cytometry, statistical analysis and prepared the manuscript. NDA coordinated the study and drafted the manuscript.

\section{Competing interests}

The authors declare that they have no competing interests.
References

1. Bayman NA, Blackhall $F$, Jain $P$, Lee $L$, Thatcher N, Faivre-Finn C: Management of unresectable stage III non-small-cell lung cancer with combined-modality therapy: a review of the current literature and recommendations for treatment. Clin Lung Cancer 2008, 9:92-101.

2. Aggarwal BB, Sethi G, Baladandayuthapani V, Krishnan S, Shishodia S: Targeting cell signaling pathways for drug discovery: an old lock needs a new key. J Cell Biochem 2007, 102:580-592.

3. Carvajal D, Tovar C, Yang H, Vu BT, Heimbrook DC, Vassilev LT: Activation of p53 by MDM2 antagonists can protect proliferating cells from mitotic inhibitors. Cancer Res 2005, 65:1918-1924.

4. Tammemagi MC, McLaughlin JR, Bull SB: Meta-analyses of p53 tumor suppressor gene alterations and clinicopathological features in resected lung cancers. Cancer Epidemiol Biomarkers Prev 1999, 8:625-634.

5. Baumann M, Zips D, Appold S: Radiotherapy of lung cancer: technology meets biology meets multidisciplinarity. Radiother Oncol 2009, 91:279-281.

6. Viktorsson K, De Petris L, Lewensohn R: The role of p53 in treatment responses of lung cancer. Biochem Biophys Res Commun 2005, 331:868-880.

7. Steels E, Paesmans M, Berghmans T, Branle F, Lemaitre F, Mascaux C, Meert AP, Vallot F, Lafitte JJ, Sculier JP: Role of p53 as a prognostic factor for survival in lung cancer: a systematic review of the literature with a meta-analysis. Eur Respir J 2001, 18:705-719.

8. Zimmermann GR, Lehar J, Keith CT: Multi-target therapeutics: when the whole is greater than the sum of the parts. Drug Discov Today 2007, 12:34-42.

9. Folini M, Pennati M, Zaffaroni N: RNA interference-mediated validation of genes involved in telomere maintenance and evasion of apoptosis as cancer therapeutic targets. Methods Mol Biol 2009, 487:303-330.

10. Blagosklonny MV, Robey R, Bates S, Fojo T: Pretreatment with DNAdamaging agents permits selective killing of checkpoint-deficient cells by microtubule-active drugs. J Clin Invest 2000, 105:533-539.

11. Blagosklonny MV: Sequential activation and inactivation of $G 2$ checkpoints for selective killing of p53-deficient cells by microtubuleactive drugs. Oncogene 2002, 21:6249-6254.

12. Demidenko ZN, Kalurupalle S, Hanko C, Lim CU, Broude E, Blagosklonny MV: Mechanism of G1-like arrest by low concentrations of paclitaxel: next cell cycle p53-dependent arrest with sub G1 DNA content mediated by prolonged mitosis. Oncogene 2008, 27:4402-4410.

13. Demidenko ZN, Halicka D, Kunicki J, McCubrey JA, Darzynkiewicz Z, Blagosklonny MV: Selective killing of adriamycin-resistant (G2 checkpointdeficient and MRP1-expressing) cancer cells by docetaxel. Cancer Res 2005, 65:4401-4407.

14. Efeyan A, Ortega-Molina A, Velasco-Miguel S, Herranz D, Vassilev LT, Serrano M: Induction of p53-dependent senescence by the MDM2 antagonist nutlin-3a in mouse cells of fibroblast origin. Cancer Res 2007 67:7350-7357

15. Kumamoto K, Spillare EA, Fujita K, Horikawa I, Yamashita T, Appella E, Nagashima M, Takenoshita S, Yokota J, Harris CC: Nutlin-3a activates p53 to both down-regulate inhibitor of growth 2 and up-regulate mir-34a, mir-34b, and mir-34c expression, and induce senescence. Cancer Res 2008, 68:3193-3203.

16. Secchiero P, Corallini F, Gonelli A, Dell'Eva R, Vitale M, Capitani S, Albini A, Zauli G: Antiangiogenic activity of the MDM2 antagonist nutlin-3. Circ Res 2007, 100:61-69.

17. Bond $G L$, Levine AJ: A single nucleotide polymorphism in the $p 53$ pathway interacts with gender, environmental stresses and tumor genetics to influence cancer in humans. Oncogene 2007, 26:1317-1323.

18. Shangary S, Wang S: Small-molecule inhibitors of the MDM2-p53 proteinprotein interaction to reactivate p53 function: a novel approach for cancer therapy. Annu Rev Pharmacol Toxicol 2009, 49:223-241.

19. Vassilev LT, Vu BT, Graves B, Carvajal D, Podlaski F, Filipovic Z, Kong N, Kammlott $U$, Lukacs C, Klein C, Fotouhi N, Liu EA: In vivo activation of the p53 pathway by small-molecule antagonists of MDM2. Science 2004, 303:844-848.

20. Huang B, Deo D, Xia M, Vassilev LT: Pharmacologic p53 activation blocks cell cycle progression but fails to induce senescence in epithelial cancer cells. Mol Cancer Res 2009, 7:1497-1509.

21. Vassilev LT: MDM2 inhibitors for cancer therapy. Trends Mol Med 2007, 13:23-31. 
22. Longley DB, Harkin DP, Johnston PG: 5-fluorouracil: mechanisms of action and clinical strategies. Nat Rev Cancer 2003, 3:330-338.

23. Garcia-Carbonero R, Supko JG: Current perspectives on the clinical experience, pharmacology, and continued development of the camptothecins. Clin Cancer Res 2002, 8:641-661.

24. Yu J, Zhang L: The transcriptional targets of $\mathrm{p} 53$ in apoptosis control. Biochem Biophys Res Commun 2005, 331:851-858.

25. Sun $S H$, Zheng $M$, Ding $K$, Wang $S$, Sun $Y$ : A small molecule that disrupts Mdm2-p53 binding activates p53, induces apoptosis and sensitizes lung cancer cells to chemotherapy. Cancer Biol Ther 2008, 7:845-852.

26. Crescenzi E, Palumbo G, Brady HJ: Roscovitine modulates DNA repair and senescence: implications for combination chemotherapy. Clin Cancer Res 2005, 11:8158-8171.

27. Bhalla KN: Microtubule-targeted anticancer agents and apoptosis. Oncogene 2003, 22:9075-9086.

28. Merten JHA, Schwab P, Frohlich R, Tokalov SV, Gutzeit HO, Metz P: A Concise Sultone Routine to Haighly Oxygenated 1,10-secoEudesmanolides-Enantioselective Total Synthesis on the Antileukemic Sesquiterpene Lactones (-)-Eriolanin and (-)-Eriolangin. Eur J Org Chem 2006, 5:1144-1161.

29. Kranz D, Dobbelstein M: Nongenotoxic p53 activation protects cells against S-phase-specific chemotherapy. Cancer Res 2006, 66:10274-10280.

30. Tokalov SV, Pieck S, Gutzeit HO: Varying responses of human cells with discrepant p53 activity to ionizing radiation and heat shock exposure. Cell Prolif 2007, 40:24-37.

31. Tovar C, Rosinski J, Filipovic Z, Higgins B, Kolinsky K, Hilton H, Zhao X, Vu BT, Qing W, Packman K, Myklebost O, Heimbrook DC, Vassilev LT: Smallmolecule MDM2 antagonists reveal aberrant p53 signaling in cancer: implications for therapy. Proc Natl Acad Sci USA 2006, 103:1888-1893.

\section{Pre-publication history}

The pre-publication history for this paper can be accessed here:http://www. biomedcentral.com/1471-2407/10/57/prepub

doi:10.1186/1471-2407-10-57

Cite this article as: Tokalov and Abolmaali: Protection of p53 wild type cells from taxol by nutlin-3 in the combined lung cancer treatment. BMC Cancer 2010 10:57

\section{Submit your next manuscript to BioMed Central and take full advantage of:}

- Convenient online submission

- Thorough peer review

- No space constraints or color figure charges

- Immediate publication on acceptance

- Inclusion in PubMed, CAS, Scopus and Google Scholar

- Research which is freely available for redistribution

Submit your manuscript at www.biomedcentral.com/submit 